\title{
The Fight against Financing Terrorism: New Challenges and Developments in Hungarian Law
}

\author{
GÁBor KovÁcs-PÉTER NyITRAI
}

\section{INTRODUCTORY}

The relevant Hungarian legal regime has been driven by the implementation of anti-terrorist sanctions brought by the United Nations Security Council (hereinafter: UNSC) and the European Council, the relevant domestic legislation has never been influenced by local experience.

The relevant EC Regulations (e.g. 88 1/2002 and 2580/2001) are self-executing in Hungary (as in all EU member states). The relevant United Nations Security Council Resolutions (UNSC resolutions) 1267 and 1373 in relation to the freezing of non-banking/ financial assets needs domestic implementation. The sanctions of the UN relevant bodies (qua non-self executing international rules) are formally only binding the states and not, so to say, the financial institutions that will eventually freeze the accounts, it is obviously the state who is bound to simultaneously bear responsibility for keeping its international obligations and uphold internal rule of law. ${ }^{1}$ The pure administrative "black listing" procedure in Hungary is fully based on the blacklist of UNSC and the Council of the EU. The procedural and substantive standards currently applied in the international black listing procedure and its national implementation do not fulfill the minimum standards of the fundamental principles of human rights and the rule of law either. Hungary is facing the problem how to implement the various sanctions regimes whilst respecting their international obligations under the European Convention on Human Rights (hereinafter: ECHR) and the UN Covenant on Civil and Political Rights (hereinafter: UNCCPR) and how to implement procedural and substantive improvements aimed at safeguarding individual human rights and the rule of law, as a matter of credibility of the international fight against terrorism, in particular an appeal mechanism against sanctions imposed by United Nations and European Union bodies.

It is important to define the social context in which legal regime imposed by the UNSC, the EU and the Hungarian Government, aimed at freezing assets and financial

${ }^{1}$ According to Article 25 of the UN Charter, States have the obligation to implement enforcement measures adopted pursuant to Article 41, which obligation they perform in accordance with their national constitutional system.

Gábor Kovács, Associate Professor in Criminal Law, Head of Department of Criminal Sciences at the Széchenyi István University, Győr, Hungary. E-mail: gkovacs@sze.hu

Péter Nyitrai, Associate Professor in Criminal Law at the Széchenyi István University, Győr, Hungary. E-mail: peternyitrai@hotmail.com

(Received: 28.03.2014; revision received: 13.05.2014; accepted: 26.05.2014) 
transactions of terrorist organizations and organs associated with anti-democratic political regimes should be treated and investigated (Pap 2006: 405-425). ${ }^{2}$ The debate over Islam or Muslim communities has not been a dominant issue in the Hungarian political discourse. There is no measurable public hostility towards the Muslim community, and, even after September 11 or March 11, Islamophobia appears to be an altogether marginal, if at all existent phenomenon or sentiment in Hungary. It is worth emphasizing that Hungary had two unrelated incidents where individuals were accused of maintaining terrorist connections: one case involved a Muslim religious leader (2004), the other, a non-nationalized immigrant doctor (2003). ${ }^{3}$

With regard to criminal statistics, it is important to note that up to the amendment of Hungarian Penal Code (HPC) in 2003 (The Act II of 2003) the incrimination of terrorist acts did not comply with the general characteristics of terrorism, therefore the cases recorded in criminal statistics were not truly terrorist acts. ${ }^{4}$ The previous wording of the Section 261 was as follows: "The person who deprives another person of his personal freedom, or seizes considerable material goods, and makes dependent the release of the person or the leaving in undamaged state, or returning, of the goods on fulfillment of a demand addressed to a state organ or social organization, commits a felony, and shall be punishable with imprisonment from five years to fifteen years." Some common crimes against persons or against property were judged as terrorist acts by courts, e.g. Decision of Supreme Court (No. 1999.439) judged as an act of terrorism when the jealous defendant deprived his partner, and his partner's daughter of their personal liberty, and made their release dependent on the claim given to the police. In Decision of Supreme Court (No. 1993.597) terrorist act was committed when the perpetrator threatened that he kills his kid unless the police negotiate with him.

2 See detailed analysis on the social aspects in Pap 2006.

3 These events received a considerable media attention but neither triggered a particularly longlasting or prominent public debate. The second case concerned a naturalized Jordanian-Hungarian dual citizen dentist who worked as imam of a mosque in Hungary, which was expecting a donation of 470000 euros from the Al Haramein Foundation (Saudi Arabia) as contribution to building a new mosque. According to media reports, US intelligence bodies has been watching the movement of this foundation's alleged money laundering activities for years and believed that the foundation is closely linked to Bin Laden's Al-Quaeda and has cell groups in several countries. The media also reported that the location where Tayseer's mosque is registered is the same as for a company called FAB Ltd, owned by a Sudanese national by the name of Hassanein, who, according to The Washington Post, was involved in arms smuggling to Bosnian Muslims and associated with Usama bin Laden. The accounts were frozen but Mr Tayseer was detained and placed under preliminary arrest only in April 2004, after someone reported to the police that on the first day of Israeli President Mose Katsav's visit, he was attempting to blow up the Jewish Museum in Budapest (the opening ceremony at the museum was part of the president's programme). Although Katsav's spokesperson in Jerusalem claimed that the attack was planned against the president of Israel, Hungarian police denied any connection between the visit and Tayseer's arrest. Nevertheless, within a few weeks, due to the lack of evidence, the Prosecutors Office dropped the case which was eventually based on just one fingerpointing allegation, by an accuser who has had a long police track record and had been extradited from Hungary on two occasions.

416 recorded terrorist acts under the Hungarian Penal Code (hereinafter: HPC), in force prior to 2003, were committed between 2002 and 2006. (Source: www.police.hu). 


\section{THE HUNGARIAN NATIONAL LEGAL FRAMEWORK}

In Hungarian national law, one cannot find any special, comprehensive statute on the law against terrorism in general and financing terrorism in particular. As far as the relationship between international and domestic law norms is concerned, Hungary follows a dualistic approach and therefore the relevant provisions are set forth partly in statutes implementing the content of the international conventions on terrorism and terrorist finance, article by article and word by word into the domestic law. Act No. LIX of 2002 implementing the International Convention for the Suppression of the Financing of Terrorism serves as a good example of this type of statutes. As a related special statute, the Act XV of 2003 on the Prevention and Combating of Money Laundering is worth mentioning. Its objective is to prevent the laundering of the proceeds of criminal activities through the financial system, the capital markets and other areas exposed to potential money laundering operations as well as to help combat the flow of funds financing terrorism. This Act has implemented the regulation of the Council Directive 91/308/EEC on prevention of the use of the financial system for the purpose of money laundering and the Directive 2001/97/EC amending Council Directive 91/308/EEC. Other binding provisions are embedded in the Act No. IV of 1978 (HPC) aiming to find harmony between the recent and the earlier adopted international instruments as well as the current national standpoints. Besides these norms, certain governmental decisions play a prominent role in the fight against terrorism and terrorist finance. However, these decisions have no direct binding effect on the individual but they are obligatory for certain authorities and other state actors.

In Hungarian law, the term "terrorism" has not been defined as such so far. Notwithstanding this fact, the term terrorist group has been identified with a statutorial definition as set forth subsection 9 of par. 261 of the HPC. This definition is based on the concept of criminal conspiracy and regards a criminal group as a terrorist group in case it consists of at least three persons organized for a longer period of time, aiming to commit crimes set forth in subsection 1 or 2 of par. 261 of HPC in a coordinated action. It must be emphasized that only the Act No. II of 2003 has introduced an amendment to the old definitional scope of terrorist activity, broadening the sphere of criminalization more sensitive to the real nature and content of terrorist activities.

Hungarian legal framework is less specific to the financing of terrorism and it is based dominantly on the law against money laundering. Due to the fact that usually these criminal activities occur jointly and they have common roots as being special forms of organized crime, they could not be treated separately in every case. The Act LXXXIII of 2001 on the fight against terrorism, and the imposition of restrictive measures serves as a good example for this approach. The Act XV of 2003 on the Prevention and Combating of Money Laundering is ruling (in the same manner) the prevention of the laundering of criminal activities through the financial system, the capital markets and other areas exposed to potential money laundering operations and the problem concerning the combat of the flow of funds for the sake of financing terrorism.

Within the EU, Financial Intelligence Unit was set up under Council Decision of 17 October 2000 concerning arrangements for cooperation between financial intelligence units of the Member States in respect of exchanging information to collect and analyze financial information. In Hungary, the National Police Headquarters (hereinafter referred to as "ORFK") has special competences within the context of international cooperation. From 2008, the competencies and duties are gradually going to be transferred to the Hungarian Customs and Finance Guard (hereinafter: HCFG). The ORFK (or HCFG) may make a 
written request to a service provider for data and information (that is considered to be a bank or business secret), which the service provider must supply, acting within its powers or in order to fulfill the written requests made by a foreign financial intelligence unit. The ORFK (or HCFG) may convey the data and information obtained to a foreign financial intelligence unit in order to perform its request, or otherwise at its own discretion if there is any information, fact or circumstance that may suggest money laundering with foreign involvement.

Government Decision No. 2112 of 2004 on the current tasks in the fight against terrorism has set up an Inter-ministerial Anti-terrorist Working Group with the aim of promoting the effective implementation of the relevant international obligations and the policies of the European Union. The head of this Group is, by office, the Minister of Justice. The Working Group works together with the Counter-terrorism Coordinative Committee set up by Government Decision No. 2239 of 2005. The Committee's main task is to exchange, gather and analyze information on suspicious terrorist activities collected by national security authorities in order to prevent the commitment of a potential crime of terrorism. The Committee is operating on the logistical basis of the National Security Office and it is headed by the deputy director of the Office in question. It must be emphasized that these Units do not have independent jurisdictional competence over terrorist finance cases, the jurisdictional authority is left to the ordinary authorities operating on the basis of criminal law statutes. Government Decisions No. 2112/2004. (V. 7.), and to the No. 2151/2005. (VII. 27.) established a national financial informational (FIU - Financial Intelligence Unit), an organ which supervises the suspicious financial operations at financial institutions. The cooperation is based on the network FIU.NET, which all EU member state units have already joined. ${ }^{5}$

\section{PREVENTION OF FINANCING TERRORISM}

The Act XV of 2003 on the Prevention and Combating of Money Laundering prescribes the relevant AML preventive measures applicable to countering terrorist finance (CFT). The Act is in full compliance with international standards, in particular with Council Directive 91/308/EEC on prevention of the use of the financial system for the purpose of money laundering and with Directive 2001/97/EC amending Council Directive 91/308/EEC. Preventive measures to be taken by the so-called service providers are primarily based on the identification obligation and reporting obligation. ${ }^{6}$ The list of service providers does not include civil, non-profit organizations, but in this respect the transparency of the non-profit

5 The unit for the reporting and the transmission of the information to the foreign financial information units is an organ within the ORFK.

${ }^{6}$ Service provider: persons who are engaged in the territory of the Republic of Hungary in

a) financial services or activities auxiliary to financial intermediation;

b) investment services, activities auxiliary to investment services or investment fund management services;

c) insurance underwriting, insurance agency or insurance consulting services;

d) commodity exchange services;

e) postal financial intermediation services, postal money transfer, accepting and delivering domestic and international postal money orders;

f) real estate agency or brokering or any other incidental services;

g) auditing; 
sector is one of the cornerstones of the government's anti-terrorist program. The Government Decision No. 2046/2007 (III. 19.), on the further tasks related to the fight against terrorism, puts a deadline in place with 31 December 2007 to review the legal environment for the non-profit sector on the basis of the recommendation of the Financial Action Task Force (hereinafter: FATF) No. VIII. ${ }^{7}$

Important steps were taken within the Regulation (EC) No. 1781/206 of the European Parliament and the European Council of 15 November of 2006 on information on the payer accompanying transfers of fund. In order to ensure the transmission of information on the payer throughout the payment chain, the Regulation provides for a system imposing the obligation on payment service providers to have transfers of funds accompanied by accurate and meaningful information on the payer.

Identification obligation of the service provider means the procedure for checking the documents to identify the customer, the customer's proxy or any authorized representative, and to record the data specified in the Act in writing. Service providers must satisfy the identification requirement when entering into a business relationship with a customer, with respect to such customer, his proxy or any other authorized representative. Service providers shall be allowed to carry out any transaction involving a sum amounting to two million Hungarian forints (being equivalent to cca. EUR 7000) or more in Hungarian forints or any other currency only for a customer, proxy or other authorized representative who has been positively identified by the service provider. The obligation of identification shall also apply when there are several transactions involved, which are in fact associated, whose combined value is two million Hungarian forints or more. In this case, the identification procedure shall be carried out in connection with the transaction when the threshold of two million Hungarian forints is reached.

The particulars of customers required to be recorded in the identification procedure are strictly defined in the Act. ${ }^{8}$ The obligation of identification shall not apply to the insurance

h) accountancy (bookkeeping), tax consulting services whether or not certified, or tax advisory activities under agency or service contract;

i) casino operations;

j) trading in precious metals, precious stones, articles, ornaments and jewelry made of precious metals and/or stones, cultural assets, works of art, or selling the above-specified assets at auctions or on consignment;

k) providing services of a voluntary mutual insurance fund;

1) providing legal counsel or notary services;

$\mathrm{m})$ the customers of the entities defined in a)-1).

7 The recommendation of FATF VIII separates these regulations into 4 groups: first financial transparency related; second related to the establishment document for the non-profit organizations to keep the main aim of the organization; third to establish an administrative background to be able to track the real non-profit organization related information. The FATF points as fourth administrative group to strengthen the control systems. Next to the internal control it is mandatory that the member states should constantly check the non-profit sector. Based on the recommendation within the control processes the following parties need to be involved: national-security, other crime persecutor authorities, financial institutions, tax authorities and the other parties from the financial sector. (Source: Financial Action Task Force on Money Laundering: i.m. www.fatf-gafi.org.)

${ }^{8}$ In the identification procedure, service providers are required to record the following particulars of customers:

a) natural persons

1) given name and surname (maiden name) and, where applicable, married name; 
contracts. The service provider is not required to perform the identification procedure with respect to a customer if it is a financial institution registered in the territory of the European Union. With regard to any transaction for the exchange of currencies involving a sum amounting to three hundred thousand Hungarian forints (cca. EUR 1100) or more, the financial service organization providing the exchange service shall be required to carry out the identification procedure.

In the event of noticing any information, fact or circumstance that may suggest money laundering, if the identification procedure has not yet been completed, the service provider shall establish the identity of the customer, proxy or other authorized representative regardless of the value limit. The service provider is not required to perform the identification procedure of a client that is itself a service provider and registered in a country whose legal system is compatible with Council Directive 91/308/EEC on prevention of the use of the financial system for the purpose of money laundering. The minister being incharge of justice matters is obliged to decree the list of countries whose legal systems are not compatible with Council Directive 91/308/EEC on prevention of the use of the financial system for the purpose of money laundering.

If the data of a customer or an actual holder cannot be identified during the identification procedure or cannot be obtained, the service provider shall not enter into a business relation and shall refuse to carry out the current transaction as well as all future ones. The customer is required to provide a written statement to the service provider as to whether he is acting in his own name or in the name and on behalf of the actual holder. If any doubt arises concerning the identity of the actual holder, the service provider shall request the customer to reconfirm the identity of the actual holder. Service providers are required to take all reasonable and appropriate measures in order to establish the identity of the actual holder.

The service providers shall keep records of all cash transactions of two million Hungarian forints (cca. EUR 7000) or more (whether in Hungarian forints or in any other currency) to indicate the customer's particulars. The service providers shall suspend a transaction where there is any suspicion of money laundering and if prompt action by the

2) address;

3) date and place of birth;

4) nationality;

5) mother's maiden name;

6) number and type of identification document;

7) in respect of foreign nationals, the particulars listed in Points 1-6 that can be established from his identification document and the place of abode in Hungary;

b) legal persons and other, unincorporated organizations

1) full name and abbreviated name;

2) address of corporate headquarters and, for foreign-registered companies, the address of the Hungarian branch office;

3) principal activity;

4) number of identification document;

5) name and position of authorized representatives;

6) identification data of agent for service of process;

c) key information pertaining to and associated with the business relation and the transaction.

If the customer is a legal person or other organization, the identity of such legal person or other organization shall be positively established in addition to that of the natural person acting in the name or on behalf of such legal person or organization. 
police is deemed appropriate to examine certain corresponding information, data or circumstance. In this case, the service provider shall immediately notify the ORFK to investigate the report. The transaction may be completed if the ORFK does not notify the service provider in writing (fax, letter, e-mail) within 24 hours concerning its actions. Under Section 10 of the Act, service providers shall retain the data and documents obtained in connection with discharging the identification obligation and their copies, and the documents verifying the performance of the obligation for ten years from the date on which they were recorded or from the date on which the report was received.

Reporting obligation of service providers means the reporting of any data, information or specifics concerning suspicion of money laundering to the competent person, and the forwarding of this report to ORFK (see more details in point V). The ORFK (or HCFG) shall be authorized to use the information received only for the purposes of combating money laundering to the extent necessary, and shall retain the data containing such information for a period of ten years. The performance of the reporting obligation shall not be regarded as a violation of bank, securities, insurance, pension fund or business secrets or the violation of restrictions on the disclosure of data or information pursuant to either a legal regulation or a contract. Under Section 52 of the Act CXII of 1996 on the request of the National Security Office, police or the prosecutor, financial institution shall provide all particulars on the requested bank account, financial transaction in written form in case of the plausible suspicion of terrorism. The financial institution shall not inform the client concerned about the information process.

The Act requires specific due diligence preventive measures to be taken in the organization of each service provider (Section 11). Accordingly, any service provider having ten or more employees shall operate an internal control and information system facilitating the identification of customers in order to prevent business relations and transactions that enable or constitute money laundering. The service provider shall provide the conditions for employees to be educated concerning the legal provisions on the crime of money laundering, to recognize business relations and transactions that enable or constitute money laundering and to be able to proceed properly in cases in which money laundering is suspected. The service providers shall adopt internal regulations to be approved by the agency exercising state and professional supervision over service providers. The agencies exercising state and professional supervision over service providers shall, in cooperation with the ORFK and in agreement with the minister being in-charge of justice matters, establish guidelines and models for drawing up the Regulations.

The Regulations must contain the following:

a) guidelines to recognize information, facts or circumstances that may suggest money laundering,

b) the procedure for identifying customers,

c) a description of the internal procedure for identifying an account's actual holder and the manner in which the customer shall make his statements pertaining to such person,

d) the procedure for carrying out the reporting obligation, including the internal control, information and data processing systems that facilitate such procedure,

e) the procedural rules and forms for reporting to the ORFK (from $2008 \mathrm{HCFG}$ ), and the form containing the data,

f) rules for handling and protecting data obtained through the identification procedures or through notifications,

g) rules concerning the training and further training of employees, 
h) codes of procedure and conduct for specific events that are to be observed by the employees in direct contact with customers,

i) the respective sections of the Penal Code covering the subject of money laundering and a description of the confidentiality requirements prescribed by legal regulation governing service providers.

The ORFK shall inspect whether the service provider operates in compliance with the requirements prescribed the Act with regard to identification, reporting, data and document storage and the training and education of employees. From 2008, the competencies and duties are transferred to the HCFG. The powers conferred upon the ORFK (or HCFG) include the on-site inspection of documents concerning the identification obligation and the reporting obligation of service providers as well as documents pertaining to the education and training requirement. If the findings of the aforementioned inspections reveal any violation of regulations or any discrepancy, the ORFK (HCFG) shall order the service provider in question:

- to restore lawful operations and eliminate the discrepancies,

- to adopt the Regulations or make revisions in the Regulations in accordance with the statutory requirements.

The failure of reporting obligation constitutes crime under Section 303/B of the HPC. Any person who fails to comply with the reporting obligation prescribed by the Act on the Prevention and Combating of Money Laundering is guilty of felony punishable by imprisonment for up to three years. In accordance with the Act CIV of 2001, the crime of the failure of reporting obligation committed by an individual person shall be attributed to the financial institution. Since June of 2007 failure by negligence has not been punishable, only intentional omission is punishable. If the failure to Comply with the Reporting Obligation does not constitute criminal procedure, the state or professional supervision of the service provider shall impose fine (HUF 10,000-100,000, which is equivalent to cca. EUR 30-300) on any service provider who repeatedly violates the obligations. The administrative decisions imposing a fine may be subject to judicial review. AML/CFT measures prescribed in the Act have been properly applied both with respect to due diligence as well as to customer processes.

The basic principles of AML/CFT regulations and preventive measures come directly from the implemented legal regimes imposed by the UN Security Council and/or the relevant bodies of the EU. Due to the preventive character of rules, the legislative approach is a mixture of the evidence-based and risk-based philosophy. Suspending measures under Section 9 of Act XV of 2003 can be taken on condition that some evidence proving the suspicion of money laundering or the finance of terrorism have been produced. However, the restrictive measures imposed by government decrees only rely on international instruments, therefore there is no particular evidence-based or risk-based domestic legal policy behind this legislation. As far as restrictive measures taken in criminal proceedings are concerned, see point V.B. (penal procedure). It has to be noted that the new regulation (EC) No. 1781/2006 of the European Parliament and of the European Council of 15 November of 2006 provides a risk-based assessment in its Article 10: "the payment service provider of the payee shall consider missing or incomplete information on the payer as a factor in assessing whether the transfer of funds, or any related transaction is suspicious, and whether it must be reported to the authorities responsible for combating money laundering or terrorist financing”. 


\section{FREEZING OF ASSETS}

In Hungarian law, the following two processes of freezing ${ }^{9}$ and seizing of assets have been established:

- the legislative-administrative restrictive measures that shall be imposed directly in government decree based on international obligation, and

- the restrictive measures of penal nature that shall be imposed in criminal proceedings.

The sanctions ordering the freezing of funds and other financial assets or economic resources against persons who commit, or attempt to commit terrorist acts or who participate in or facilitate the commission of such acts "arrived" in the Hungarian legal system with Act LXXXIII of 2001, an anti-money laundering and anti-terrorism package which (motivated far more by the European Union integration process ${ }^{10}$ than a fear of terrorism) contained a host of new measures and regulations intended to aid the global effort to combat terrorism, especially in the area of financial sanctions and restrictions towards organizations and persons supporting terrorism. The Act authorized the government to issue decrees which for 90 days can enforce and impose financial and economic sanctions posed by the UN Security Council or EU Council. The Act says that if the restrictive measure requires an Act-based enforcement, the Parliament shall take the appropriate legislative measure within 90 days. Through the enforcement of EC regulations and UNSC resolutions, the government is entitled to introduce economic, commercial, financial or other prohibition or restriction vis-a-vis states, foreign or domestic natural or legal persons. It is important that the legislative restrictive measure shall be based on an obligation to which Hungary is committed under international law UNSC resolutions, or ordered in the regulations adopted under Article 60 of the Treaty establishing the European Community, or in regulations and decisions adopted by authorization of these regulations, or ordered in the Council's common position adopted under Article 15 of the Treaty on the European Union. Under Section 261/A. "Violation of International Economic Restrictions", any person who violates the obligation imposed on the basis of an obligation to which Hungary is committed under international law, or ordered in regulations is guilty of a felony punishable by imprisonment for up to five years (see more in point V). As sanction-type resolutions often carry severe restrictions on the right to property, or even criminal liability, an act of parliament would be the desirable medium for implementation from the constitutional law point of view.

Government decrees implementing EC and UNSC resolutions contain that the general rules of administrative procedures should apply in the procedures freezing or seizing assets where the National Police shall act as a first instance and the Ministry of Internal Affairs as the second instance.

Designation lists: Government decrees (e.g. No 56/2002. (III.29.) on the restrictive measures based on international obligations in the fight against the terrorism) provide

9 Concerning freezing measures under the Section 9 of the Act XC of 2003 the service providers shall suspend a transaction where there is any suspicion of money laundering and if prompt action by the police is deemed appropriate to examine certain corresponding information, data or circumstance. In this case, the service provider shall immediately notify the ORFK to investigate the report. The transaction may be completed if the ORFK does not notify the service provider in writing (fax, letter, etc.) within 24 hours concerning its actions taken in accordance with the Act on Criminal Proceedings. The 24-hour period shall not include Saturdays, Sundays and official holidays.

10 It is especially noteworthy that in June 2001 Hungary was put on the FATF/OSCE blacklist of countries non-conforming in money laundering issues. 
designation lists. Financial rights, financial means, properties of, and enterprises directed by person, group, firm or institution listed in the decrees are to be frozen. Bank accounts, financial transactions related to frozen accounts, business shares shall also be included in the frozen assets. Decree designation list contained persons and organizations listed e. g. Regulation EC No. 881/2002.; Regulation EC No. 1210/2003.; Regulation EC No. 314/2004.; Regulation EC No. 798/2004.; Regulation EC No. 872/2004.; Regulation EC No. 1763/2004. ; UN Security Council R. No. 1390 (2002).

To summarize, the "Hungarian" blacklists are not criminal lists, the sanctions do not impose a criminal punishment of procedure but instead apply legislative-administrative measures. The sanctions are civil in nature. According to the definition proffered by the ECtHR in König case, the substance and the effect of the right under the domestic law of the State concerned must be examined. Freezing of assets appears to have a civil quality, but it also has a criminal character by limiting freedom of movement. Regardless of the characterization, which is open to debate, the fair trial guarantees under the ECHR, ICCPR, or customary international law are not met by the current UN and EU listing procedures. There is no type of hearing, public or private, before an individual or entity is listed. The absence of such a hearing necessarily precludes it from occurring before an "independent and impartial tribunal", but, in any case, the members of the sanctions committees are not "independent and impartial". A tribunal cannot meet those qualifications when the members serve multiple functions as both prosecutor and judge

Without specific restriction measure ordered by an Act of Parliament or a government decree (based on international obligation derived from EC or UNSC resolutions) on a given natural or legal person, a full fledged freezing of assets can only be ordered in the course of criminal procedure or as part of an operation induced by international criminal cooperation.

Under Section 159 of Hungarian Code on Criminal Procedure (hereinafter: HCP), during the whole period of criminal proceedings, sequestration shall be ordered by a judge either if the civil forfeiture is likely to be imposed as a result of the proceedings or civil claim was submitted and there is reasonable ground to suppose that the property may be deprived of the civil claim. Sequestration may also be imposed on legal persons. Under Section 160 of the HCP, special security measures shall be taken by police or prosecutor to ensure the prospective sequestration through the suspension of rights of disposition of the suspected person related to goods, real estate property, bank accounts, business shares, stock or any financial means. Any financial means obtained by a legal person shall also be subject to security measure. Irrespective of the matter of guilt, civil forfeiture shall be imposed to seize any financial gain or advantage resulting from criminal activities, obtained by the offender in the course of or in connection with, a criminal act and any property that was supplied or intended to be used to finance the means used for the commission of a crime, the conditions required therefore or facilitating that - for the purpose of this criminal measure - any profits, intangible assets, claims of any monetary value and any financial gain or advantage are deemed assets. This criminal measure shall also be imposed on legal persons.

The HPC lays down that for the purposes of all legal regulation promulgating an obligation 'funds, other financial assets and economic resources' means the assets specified in Point 1 of Article 1 of Council Regulation (EC) No. 2580/2001 of 27 December 2001 on specific restrictive measures directed against certain persons and entities with a view to combating terrorism; 'freezing of funds, other financial assets and economic resources' shall have the meaning conveyed in Point 2 of Article 1 of Council Regulation (EC) No. 
2580/2001 of 27 December 2001 on specific restrictive measures directed against certain persons and entities with a view to combating terrorism.

No documented cases about charitable organizations listed or de-listed in government decrees implementing lists of EC regulations and UNSC resolutions can be found. One Hungarian case related to a charitable organization deserves to be mentioned that was charged with providing financial support to terrorist organizations and in one way or another started off from bank reports. This case also shows the inconsistencies within criminal law and UNSC resolutions or EU-induced anti-terrorist legislation.

The first case involved Kinan Haddad, a Syrian physician who had been working in Hungary for several years and was summarily expelled in 2003 after he had transferred money to a bank account for a charity that was linked to a terrorist organization. Following the bank's report to the National Security Office, Interior Ministry's Immigration and Citizenship Office summoned Dr Haddad, notified him that the account number to which he made this donation was linked to Hamas, extradited him and told him he could not return for 10 years. Although he said he had not known who was behind the account, the National Security Office insisted that as the account belongs to one of the cover organizations of Hamas, in such cases, expulsion is the only possible reaction. Because the action was taken without a proper investigation and Dr Haddad was not given an opportunity to defend himself and therefore was not afforded due process of law, the Helsinki Commission claimed that the Hungarian expulsion process conflicts with general human rights principles and leaves no room to mount a legal defense. (Some argued that the fact that Dr Haddad was separated from his wife, with whom they got married according to Islamic law, constituted a breach of Article 8 of the European Convention on Human Rights.) Dr Haddad's lawyer filed appeals with several government agencies but received no replies. Commentators draw attention to the following controversy: were the national security charges well-founded, an ex-officio criminal procedure should have been initiated. As it was not done, the factual and legal basis for the extradition remains questionable.

\section{PENAL MEASURES}

With regard to the financing of terrorism, the HPC contains special direct incrimination and more general indirect incrimination.

The direct criminalization of the financing of terrorism is placed within the Section 261 of HPC (Act of Terrorism) in a sense that its mental and subjective elements are closely linked to the elements of a terrorist act, as principal crime.

Indirect incrimination has a more extended scope, however, through the incrimination of illegal finances and the violation of related obligations, it relates closely to the terrorism, as such. We consider as indirect incrimination the money laundering and the violation of international obligations.

Under the Section 260 of HPC, two forms of the act of terrorism, as principal crimes are as follows:

- any person who commits a violent crime against one of the persons referred to in Subsection $(9)^{11}$ or commits a crime that endangers the public or involves the use of a firearm in order:

11 a) 'violent crime against a person and crime of public endangerment that involves the use of firearms' shall mean homicide [Subsections (1) and (2) of Section 166], battery [Subsections (1)-(5) of Section 170], willful malpractice [Subsection (3) of Section 171], violation of personal freedom 
a) to coerce a government agency, another state or an international body into doing, not doing or countenancing something;

b) to intimidate the general public;

c) to conspire to change or disrupt the constitutional, economic or social order of another state, or to disrupt the operation of an international organization;

is guilty of a felony punishable by imprisonment between ten to fifteen years, or life imprisonment. [subsec. 1]

Any person who seizes considerable assets or property for the purpose defined in Point a) and makes demands to government agencies or non-governmental organizations in exchange for refraining from harming or injuring said assets and property or for returning them shall be punishable according to Subsection (1). [subsec 2.]

Providing financial means to abet an act of terrorism which was already commenced is considered to be an accessory form of perpetration of a terrorist crime (subsec (2) of Section 21 of HPC). Accomplice is a person who knowingly and voluntarily helps another person to commit a crime. The item of punishment established for the perpetrators shall also be applied for the accomplices. After the attempt ${ }^{12}$ of the principal terrorist act, the previous agreement on financing or the previous offer of it, in itself is also punishable as a form of accessory under the Section 21 of HPC. The person abetting the accomplice shall also be punished as accomplice of the perpetrator.

With respect to mental elements, accessorial liability needs the mental and material elements of the accessory to be related to a given act of terrorism and to an individual perpetrator preparing or attempting an act of terrorism. The general aim of terrorist activity on the part of a person abetting others is not sufficient to consider him/her as an accomplice except only if the abettor's mental element fits the broader criminalization defined in subsec (5) of sec 261. Any form of financing by negligence of a terrorist act is not punishable.

Prior to the commencement of the terrorist act, its financing is punishable under different forms of special preparatory acts in subsec. (4) of sec 261 according to which, any person who

a) invites, offers for, undertakes the perpetration of terrorist act (subsec. (1) and (2)), or agrees on joint perpetration of terrorist act or

(Section 175), kidnapping (Section 175/A), crimes against transportation safety [Subsections (1) and (2) of Section 184], endangering railway, air or water traffic [Subsections (1) and (2) of Section 185], violence against public officials (Section 229), violence against persons performing public duties (Section 230), violence against a person aiding a public official (Section 231), violence against a person under international protection (Section 232), public endangerment [Subsections (1)-(3) of Section 259], interference with public works [Subsections (1) and (2) of Section 260], seizure of an aircraft, any means of railway, water or road transport or any means of freight transport (Section 262), criminal misuse of explosives or explosive devices (Section 263), criminal misuse of firearms or ammunition [Subsections (1)-(3) of Section 263/A], arms trafficking (Section 263/B), criminal misuse of radioactive materials [Subsections (1)-(3) of Section 264], criminal misuse of weapons prohibited by international convention [Subsections (1)-(3) of Section 264/C], crimes against computer systems and computer data (Section 300/C), vandalism (Section 324) and robbery (Section 321);

12 If any of the crime listed in subsec. (9) of sec. 261 (see above) begins with special purpose prescribed in subsec (1) of 261 (see above), the act of terrorism is considered as attempted, i.e. the attempt of a homicide with special purpose prescribed in subsec. (1) or obtaining, possessing firearms or ammunition without a license with special purpose defined in subsec. (1) shall be punished as an attempt of a terrorist act. 
b) provides for the perpetration of a terrorist act (subsec. (1) and (2)) the conditions required therefore or facilitating that or financial means or

c) gathers financial means for the perpetration of a terrorist act (subsec. (1) and (2)).

Due to its preparatory form, incrimination under subsec (4) is applicable only prior to the attempt of the terrorist criminal act which was aimed to be supported. If the terrorist act was attempted, the person who previously provided financial means shall be punished as an accomplice of the terrorist act (subsec. (1) or (2)). Attempt of the above defined sui generis preparatory acts is also punishable with the same item of punishment as it is established for the perpetration of the subsec. (4).

Intellectual forms of perpetration, such as providing knowingly and voluntarily any advice or information, even in relation to the financial conditions of the crime,

a) if a terrorist act was attempted, it is punishable as accomplice of the perpetration of the terrorist act (subsec. (1) or (2)),

b) up to the attempt of a terrorist act, it is punishable under subsec. (4), if the advice or information facilitate effectively the prospective perpetration of the terrorist act (subsec. (1) or (2)).

Under subsec. (4), per se incrimination of conspiracy for a terrorist act is punishable; however, if the conspiracy is directed only to the financing act, it is not punishable in itself. Conspiracy for financing operates if at least two persons agree on the joint financing of an act of terrorism; a person invites another to finance a terrorist act or a person offers or undertakes to finance a terrorist act. The agreement with a member or the members of the conspiracy on the support (prior to the perpetration and without the actual attempt of the terrorist act) can not be considered as a punishable preparatory act. The preparation for supporting a preparatory act (defined in subsec. (4)) is in itself not punishable. However, if the agreement was made on providing support during the perpetration of a terrorist act, it shall be punished as preparatory act for a subsequent accessory role under subsec. (4). In other word, up to the attempt of terrorist act, the conspiracy is punishable only if the financial support is offered or agreed to be provided during the perpetration of the terrorist (in this case it is considered as an undertaking or offering the contribution as accomplice during the prospective perpetration), otherwise, up to the attempt of terrorist act, the offer or the agreement in itself is punishable under subsec. (4), only if the offer or the agreement may effectively facilitate the prospective perpetration of the terrorist act (subsec. (1) or (2)). If the act of terrorism was effectively attempted, the previous agreement, offer or conspiracy related to either the support prior to the perpetration or a support to provide during the perpetration shall be punished as a psychical accessory act of subsec. (1) or (2). If the material support was provided as it had been agreed or offered, it is a material preparatory act up to the attempt of the act of terrorism, and it is an accessory act if the act of terrorism was attempted.

It has to be noted that a person who offers or agrees on the financial support prior to the attempt of the terrorist act needs to have special intention related to a given act of terrorism which is aimed to be committed by an individual. The person abetting perpetrator of the supporting or facilitating act prior to the attempt of the terrorist act is also punishable as accomplice of accomplice, and as accomplice of the subsec. (4). The general minimum requirement is that the support shall be directed to an individual or individuals involved in the preparation (or in a conspiracy) of a special act of terrorism. The general aim of conspiracy for a support of general terrorist goals without any mental relation to a special prospective terrorist act and individual or individuals involved in the given act does not fulfill the mental requirements to punish preparatory acts defined in subsec. (4). 
The per se preparation for the financial support (i.e. gathering, obtaining or possessing money for support of a terrorist act without transferring it) is also punishable under special criminalization subsec. (4). In this respect, an overt act which proves that the financial means were planned to be directed to the support of a terrorist act needs to take place. Moreover, it can be per se criminal act such as money laundering (see indirect incrimination).

With respect to mental elements, supporting knowingly general terrorist goals of a person or persons does not fulfill the mental requirements of subsec. (4). The mental and material elements of the preparatory act need to be related to a given act of terrorism and to an individual perpetrator preparing or attempting the act of terrorism. The general aim of terrorist activity on the part of a person abetting others is not sufficient to consider him/her as guilty except only if the mental element fits the broader criminalization defined in subsec. (5) of Section 261 of HPC. Any form of financing by negligence of a terrorist act is not punishable.

It has to be added that the Section 137 of HPC provides a general definition of "criminal conspiracy" ("when two or more persons are engaged in criminal activities under arrangement, or they conspire to do so and attempt to commit a criminal act at least once, however, it is not considered a criminal organization"). The Section 137 is an interpretative rule for criminal conspiracy, not a sui generis incrimination of that, that is applied as a special aggravating form of certain crimes in HPC and is punishable as such only if the crime has already been attempted by members of the conspiracy.

The special aggravating form of the preparatory acts occurs if any person who commits any acts defined under Subsections (4) for the perpetration of any of the criminal acts defined under Subsections (1) and (2) in a terrorist group or supports the activity of a terrorist group in any other form. Under subsection (5), this is a felony punishable by imprisonment between five to ten years. "Terrorist group" means a group consisting of three or more persons operating in accord for an extended period of time whose aim is to commit the terrorist act defined in Subsections (1)-(2).

Special aggravating element compared to subsec. (4) is that preparatory acts shall be directed to support a terrorist act prepared by a terrorist group. This aggravating form is applicable only prior to the attempt of the terrorist criminal act which was aimed to be supported. If a terrorist act was attempted, the person who previously prepared for providing financial means to a terrorist group is guilty of accomplice of the subsections (1) or (2). It is important to note that perpetration of a terrorist act defined in subsections (1)-(2) in a terrorist group, in itself is not a special aggravating form of the principal subsections (1) and (2). However, the organized perpetration of a crime is considered as a general aggravating circumstance of the sanction in a way that the judge is entitled to raise the maximum item of the penalty by $50 \%$. Organized perpetration means that a group of three or more persons collaborate to deliberately engage in an organized fashion in the given criminal act.

Some special mental elements are required compared to subsec. (4) in which the perpetrator has to know and foresee the intention of a given individual or individuals who are supported by himself/herself. Due to organizational links, under subsec. (5) the perpetrator has to know the common goal of the terrorist group whose member or members are aimed to be supported. The perpetrator must also know that the crime which is aimed to be supported is planned to be committed by a group consisting of at least three persons operating in accord for an extended period of time and whose aim is to commit terrorist crimes defined in Subsections (1)-(2). In addition, a perpetrator must be aware of the terrorist character of the crime supported which means that he/she supposes that the act 
(which is effectively an act of terrorism) is a "terrorist one" or he/she realizes some typical elements of terrorist crimes in accordance with the common definition of "terrorism" that could be supposed to be known by each average person. This non-legal definition of terrorism is a subject of assessment that has to be made by the judge. ${ }^{13}$ In Hungarian judicial practice a guideline definition of terrorism that could be used as a yardstick of the average level of knowledge in searching for the content of the individual intention has not been commonly accepted and established yet.

If the perpetrator of the preparatory act defined in subsec. (5) does not realize or foresee the "terrorist type" of crime which is planned by a terrorist group, he/she may be punishable for the 'affiliation with organized crime' (under the Section 263/C. of HPC) if the criminal acts which are aimed to be supported were effectively punishable with five years of imprisonment or more.

Any form of financing of a terrorist act by negligence is not punishable. Negligence means that the perpetrator financially supporting an activity is not aware that the related activity is directed to a terrorist act.

The HPC has extended considerably the incrimination when considered the financing related to a person who only threatens to commit a terrorist act as a specific crime. Under the general rule of the HPC, threatening to commit a crime is not considered as punishable attempt or preparation of the criminal act. However, in accordance with subsec. (7) of Section 261, threatening to commit a terrorist act is a per se criminal act of terrorism (a felony punishable by imprisonment between two and eight years), irrespective of how seriously the perpetrator takes the threatening. Providing finances or material means to the person menacing to commit terrorist act is an accessory act of the subsec. (7), however, if the accessory's intention does extend to the support of a prospective act of terrorism prescribed in subsec. (1) or (2) too, it shall be punished as accessory related to terrorist acts defined in subsec. (1) or (2), on condition that the terrorist act is attempted. If the "terrorist" purpose can not be proven, the general criminalization of that is the threatening with 'public danger' under the Section 270/A of HPC, according to which a person who, in the presence of others, states an untrue fact suitable for disturbing public peace, that there is a menace of the occurrence of an event involving public danger, commits a misdemeanor and shall be punishable with imprisonment of up to two years, labor in the public interest, or a fine. The punishment for felony shall be imprisonment of up to three years, if the crime is committed by threatening with a radioactive substance.

The perpetrator or accomplice of any form of the Section 261 can be any person who has reached the age of fourteen at the time the act was committed. Under Section 4, Hungarian criminal law shall be applied to any act committed by non-Hungarian citizens in a foreign country, if the crime committed is to be criminalized under the strength of an international treaty (universal jurisdiction). The official reasoning of the Act II of 2003 introducing the present form of crime of a terrorist act into HPC referred explicitly to the International Convention for the Suppression of the Financing of Terrorism (which was implemented by the Act LIX of 2002) as the international legal basis of the criminalization. Due to this reasoning, Section 261 and related incriminations are to be judged under the universal jurisdiction of HPC.

13 According to the International Convention of the Suppression of the Financing of Terrorism (New York) Article 2., it seems to be a good guideline definition for domestic tribunals in description of the common notion of term "terrorism". 
Under subsection (8) of Section 261 ratione personae of the section is extended to persons (including family members) who have positive knowledge concerning plans for a terrorist act and fail to promptly report that to the authorities. This is a felony punishable by imprisonment for up to three years. Any preparatory act defined in subsections (4) or (5) such as financing the preparation of a terrorist act or a conspiracy for support of a terrorist act have to be seen as a plan for a terrorist act, thus a person who is aware of those preparatory acts shall be punished as the perpetrator of subsection (8) of Section 261. With this regard, the procedural exemptions of certain witnesses to make testimony (under the Sections 81 and 82 of HCP) are not exemptions regarding the general obligation for making report laid down in HPC. The defense council can not be interrogated as witnesses on the issues of which $\mathrm{s} /$ he was aware as defense council. The other procedural exemption is that a relative of the person charged in the criminal procedure and any person who would charge himself/herself or his/her relative with his/her testimony has the right not to make testimony. Those persons are obliged to promptly report to the authorities if he or she is aware of plans for a terrorist act. Procedural exemptions are applicable only to the procedure of evidences, but under the substantive criminal law, the defense council is punishable if knowing that his client is planning to commit a terrorist act remains silent, and a relative of the perpetrator is also punishable if he fails to report his family member planning to commit a terrorist act.

In accordance with the Act CIV of 2001, the crime of financing of terrorism committed by an individual person shall be attributed to a legal person on the following conditions:

If the crime was intended to make financial benefit for the legal person or resulted in financial benefit for the legal person and the crime was committed either

- by head of business or representative or agent within the business activity of the legal person; or

- by employee or member within the business activity of the legal person and the crime would have been precluded if the responsible leader had accomplished his/her supervisory or control duties; or

- by anyone if the crime resulted in financial benefit for the legal person and the head of business or representative or other entitled employee or member who was aware of the crime.

The attribution of the crime to the legal person requires a motion submitted by the prosecutor in the criminal proceedings. The following penal measures can be imposed to the legal persons: dissolution, restriction of its activity and monetary fine. The condition of the dissolution is that the legal person does not pursue any effective and legal for-profit activity and it shall be established for covering crimes or its activity aims at covering crimes.

As it was described previously, financing of terrorism forming preparatory acts defined in subsections (4) and (5) is a sui generis form of incriminated preparation that does not fall within the scope of the general justification rule of Section 18 concerning the preparation of a crime, although, sui generis preparatory acts are substantively the same as the elements of the general rules of preparation. For the above reason, instead of general justification rule (subsection (2) of section 18. $)^{14}$, the following special rule shall apply: in the phase of

14 (2) Prosecution for preparation shall not apply against a person:

a) who voluntarily discontinues his participation in the preparation before the act is committed;

b) who withdraws his invitation, offer, undertaking with the aim of the prevention of the perpetration, or attempts to pursue other contributors to withdraw from the criminal activity, provided that the commencement of the perpetration does not take place for any reason whatsoever;

c) who informs the authority about the preparation. 
preparation, the perpetrator of a criminal act defined in Subsection (4) or (5) shall not be liable for prosecution if he confesses the act to the authorities before they become aware of it and reveals the circumstances of the criminal act. It is also applicable if the accomplices of the "pentiti" attempt the crime jointly prepared.

General justification rules related to the attempt are to be applicable in a way that if the perpetrator attempts to commit any form of Section 261, including attempt of preparatory acts providing financial means (defined subsections (4) or (5)), according to general rule of subsection (2) of Section 17., s/he shall not be liable for prosecution for attempt, if s/he voluntarily withdraws from the criminal activity before it is committed. If the attempt in itself constitutes another crime, the perpetrator shall be liable for prosecution for that crime.

In relation to withdrawal from any form of terrorist crime, special mitigating rule of Section 261 terrorist act shall be applied: the punishment of any person who:

a) abandons commission of the criminal act defined under Subsections (1) and (2) before any grave consequences are able to materialize; and

b) confesses his conduct to the authorities;

in such a manner as to cooperate with the authorities to prevent or mitigate the consequences of such criminal act, apprehend other coactors, and prevent other criminal acts may be reduced without limitation.

Financing of terrorism is often related to other specific crimes which constitute sui generis preparatory element facilitating providing financial means to a terrorist act. Incrimination of violation of international and domestic economic restrictions aims to impose criminal sanction on the violation of anti-terrorist legal measures. Under the Section 261/A., any person who violates:

a) the obligation for freezing liquid assets, other financial interests and economic resources;

b) an economic, commercial or financial restriction;

imposed on the basis of an obligation to which Hungary is committed under international law, or ordered in regulations adopted under Article 60 of the Treaty establishing the European Community, or in regulations and decisions adopted by authorization of these regulations, or ordered in the Council's common position adopted under Article 15 of the Treaty on the European Union, is guilty of a felony punishable by imprisonment for up to five years. The incrimination of the preparation is laid down in subsec. (4): any person who engages in preparations for the violation of any international economic restriction shall also be punishable for a felony by imprisonment of up to three years. The incrimination is extended to any person who has positive knowledge of preparations being made for the violation of any international economic restriction or that such a crime has been committed and is as yet undetected, and fails to promptly report that to the authorities. In this specific case, relatives of the persons committing the offense of misprision shall not be liable for prosecution. Unless otherwise prescribed by legal regulation promulgating an obligation or restriction under international law: a) 'funds, other financial assets and economic resources' means the assets specified in Council Regulation (EC) No. 2580/2001 of 27 December 2001 (Point 1 of Article 1) on specific restrictive measures directed against certain persons and entities with a view to combating terrorism; b) 'freezing of funds, other financial assets and economic resources' are defined in Council Regulation (EC) No. 2580/2001 of 27 December 2001 (Point 2 of Article 1) on specific restrictive measures directed against certain persons and entities with a view to combating terrorism. 
Due to a recent modification, the scope of the AML incrimination became broader from June of 2007. Under section 303., "any person who transforms, transfers, uses in his business activity, undercover rights related to or place where the thing is located, or pursues any financial activity or financial service concerning a thing resulting from a criminal act punishable by imprisonment committed by another person, or seizes, handles, uses those thing, in order to conceal its true origin is guilty of felony punishable by imprisonment for up to five years". The previous incrimination was also maintained: "any person who uses things obtained by the commission of criminal activities punishable by imprisonment in his business activities and/or performs any financial or bank transaction in connection with the thing in order to conceal its true origin is guilty of felony punishable by imprisonment for up to five years". New regulation also maintained the incrimination of ML conspiracy (subsection 5.) and a special justification according to which the person who voluntarily reports to the authorities or initiates such a report shall not be liable for prosecution for money laundering, provided that the act has not yet been revealed, or it has been revealed only partially. Money laundering by negligence remained to be punishable (under Section 303/A.) as follows: any person who uses a thing obtained from criminal activities punishable by imprisonment committed by others:

a) in his business activities, and/or

b) performs any financial or bank transaction in connection with the thing,

and is negligently unaware of the true origin of the thing is guilty of misdemeanor punishable by imprisonment for up to two years, community service work, or a fine. Related special justification was extended to ML by negligence: the person who voluntarily reports to the authorities or initiates such a report shall not be liable for prosecution for money laundering, provided that the act has not yet been revealed, or it has been revealed only partially.

AML Reporting Obligation: under Section 303/B., any person who fails to comply with the reporting obligation prescribed by the Act XV of 2003 on the Prevention and Combating of Money Laundering is guilty of felony punishable by imprisonment for up to three years. Up to the modification of 2007 , the failure by negligence to comply with the reporting obligation related to money laundering has been a misdemeanor punishable by imprisonment for up to two years, community service work, or a fine. Since June 2007 failure by negligence has not been punishable, only intentional omission is punishable. The Act XV of 2003 lays down the special reporting obligation (Section 1 subsec. 1.) on the basis of the Council Directive 91/308/EEC on prevention of the use of the financial system for the purpose of money laundering and on the Directive 2001/97/EC amending Council Directive 91/308/EEC. Reporting is legal duty for the persons being engaged in the territory of Hungary in

a) financial services or activities auxiliary to financial intermediation;

b) investment services, activities auxiliary to investment services or investment fund management services;

c) insurance underwriting, insurance agency or insurance consulting services;

d) commodity exchange services;

e) postal financial intermediation services, postal money transfer, accepting and delivering domestic and international postal money orders;

f) real estate agency or brokering or any other incidental services;

g) auditing;

h) accountancy (bookkeeping), tax consulting services whether or not certified, or tax advisory activities under agency or service contract; 
i) casino operations;

j) trading in precious metals, precious stones, articles, ornaments and jewelry made of precious metals and/or stones, cultural assets, works of art, or selling the above-specified assets at auctions or on consignment;

k) providing services of a voluntary mutual insurance fund;

1) providing legal counsel or notary services;

m) the customers of the entities defined in Paragraphs a)-l) (hereinafter referred to collectively as 'service provider'), and any person who crosses the border of the Republic of Hungary;

n) directors, managers and employees of service providers and their participating family members.

The obligations of reporting shall apply to attorneys if they hold any money or valuables in custody or if they provide legal services in connection with the preparation and execution of the given transactions in accordance with the Act XI of 1998 on Attorneys:

a) buying or selling any participation (share) in a business association or other economic organization,

b) buying or selling real estate,

c) founding, operating or dissolving a business association or other economic organization.

If the failure to Comply with the Reporting Obligation does not constitute criminal procedure, the state or professional supervision of the service provider shall impose fine on any service provider who repeatedly violates the obligations.

There are some criticisms in relation to the criminal law framework stating that the system is producing a high volume of low quality over-reporting from financial institutions. This regime appears to have led to a large amount of "defensive reporting," rather than attempts to identify genuinely suspicious individuals, as very few of the reports have led to investigations and none to prosecutions. Out of 14120 reports received in 2004, a small number, to be precise, only 20 cases turned into investigations.

The incriminations described above are punishable by imprisonment, community service work, or a fine as it was specified to each specific crimes in the above points (principal punishments). The following ancillary punishments are also applicable: deprivation of civil rights, restraint of profession, suspension of driving privileges, banishment, expulsion, fines as ancillary punishment. Specific penal measures may also be applied independently and in addition to a punishment, namely confiscation and civil forfeiture. In terms of financial outcomes of financing activities related to terrorism, civil forfeiture needs to be dealt with in depth. Under Section 77/B. the following shall be subject to civil forfeiture:

a) any financial gain or advantage resulting from criminal activities, obtained by the offender in the course of or in connection with, a criminal act;

b) any financial gain or advantage obtained by an offender in connection with crimes committed in affiliation with organized crime;

c) any financial gain or advantage that was used to replace the financial gain or advantage obtained by the offender in the course of or in connection with, a criminal act;

d) any property that was supplied or intended to be used to finance the means used for the commission of a crime, the conditions required therefore or facilitating that;

e) any property embodying the subject of financial gain.

Any financial gain or advantage resulting from criminal activities, obtained by the offender in the course of or in connection with, a criminal act, also if it served the 
enrichment of another person, shall be seized subject to civil forfeiture. If such gain or advantage was obtained by an economic operator, it shall be subject to forfeiture. In the event of death of the perpetrator or the person profiteering; or when the economic operator was transformed, the property transferred by succession shall be seized from the successor in title. All assets obtained by the perpetrator during his involvement in organized crime shall be subject to forfeiture until proven otherwise. The property cannot be seized if that is reserved to cover any civil claim awarded during the criminal proceeding or that was obtained in good faith for consideration. Any profits, intangible assets, claims of any monetary value and any financial gain or advantage shall be deemed assets.

Relevant procedural rules related to the civil claims for compensation are as follows:

- civil claim for compensation can be awarded during criminal proceedings,

- if the property is reserved to cover any civil claim awarded during criminal proceeding, this can not be subject to civil forfeiture,

- during criminal proceedings, the judge may order sequestration of the property if a related civil claim was submitted and there is a reasonable ground to suppose that the property is likely to be deprived of civil claim. (Section 159 of HCP)

The Act CXXXV of 2005 on the aid for victims of crimes and the mitigation of damages by the states prescribes general measures with purpose to state-financed compensation for all victims of any intentional crimes. The regulation is based on the EU Directive on the compensation of victims of crimes according to which each EU Member State shall ensure mitigation of damages suffered by EU citizens who became victim of any violent and intentional crime committed within the territory of the EU. Definition of a victim: all natural persons who suffered any kind of harm (physical, moral, financial, etc.) resulting from any activity which is considered as a crime under the criminal law of any EU Member State. Persons entitled to be compensated shall be either

- EU citizens, or

- non-EU citizens, or

- persons having permit of residence, or

- any other persons who are victims of human traffic, or

- entitled to be compensated on the basis of a bilateral international agreement.

The Act defines three principal services to be provided for victims:

- legal services in claiming for compensation,

- prompt financial aid,

- legal advice.

Aid services and mitigations of damage shall be provided by the State Victims Aid Office. Legal service shall be provided for the victim under the Act LXXX of 2003 on the Legal Aid. The prompt financial aid is not provided automatically, its payment and its amount depend on individual circumstances of the given case. This is a lump-sum that is to mitigate the prompt damages therefore its maximum amount is $50 \%$ of the official average individual income/per mount according to the National Statistical Office (nearly EUR 500) (the so-called 'basic amount'). The final amount of the compensation may be up to 15 times greater than the basic amount. The compensation is total if the damages are less than 5 times greater than the basic amount. The compensation is partial ( $\max 75 \%$ of the damages) if the damages are between 5 times and 10 times greater than the basic amount. The compensation is max. $50 \%$ of the damages if the damages are more than 10 times greater than the basic amount.

In Hungarian law, there are no provisions or practices regarding the use of confiscated or forfeitured assets for compensating victims of any crime. 
Another type of possible remedy is monetary compensation (Article 14(6) of ICCPR and Article 3 of Protocol No. 7 to the ECHR). To date, however, no court has allowed any type of "punitive damages" for compensation. Recently, for example, Sison applied to the CFI for compensation under Article $288 \mathrm{EC}$, but his claim was rejected.

Restrictive penal measures fully comply with national fundamental legal principles as well as international legal standards. Human rights problems relate to the freezing of assets done directly through legislation process implementing designation lists of EC regulations or UNSC resolutions. The procedural and substantive standards currently applied by the UNSC and by the Council of the EU, despite some recent improvements, in no way fulfill the minimum standards of the fundamental principles of human rights and the rule of law. The person or group concerned is usually neither informed of the request, nor given the possibility to be heard, nor even necessarily informed about the decision taken - until he or she first attempts to cross a border or use a bank account. There are no procedures for an independent review of decisions taken, and for compensation for infringements of rights. Recent cases before the European Court of Justice (ECJ), the First Instance Court of the ECJ (CFI) and the European Court of Human Rights (ECtHR) have raised serious questions about the UNSC and EU sanctioning procedures targeting individuals and entities. While no court to date has invalidated any national or regional measures implementing a UNSC resolution, the rising number of legal challenges suggests an increasing awareness of the procedures' lack of protection for fundamental human rights. Hungary is facing the deficit of protection for human rights in the UNSC and EU sanctions regimes and, in particular, the inadequacies of the listing and de-listing procedures and the lack of remedies.

The financial sanctions freezing funds and other economic resources impact on the right to property and right to work as defined under Article 1 of Protocol No. 1 to the ECHR (right to property) and Article 6 of ICESCR (the right of everyone to earn their living by work). The most grievous human rights violation occurs in the sanctions regimes' disregard for "fair trial" rights in their listing procedures. The Article 6 of ECHR guarantees a "fair and public hearing within a reasonable time by an independent and impartial tribunal established by law" in the case of both civil and criminal charges. If the state receives a Security Council resolution which is based on mostly unrevealed sources of information and political deliberations (invariably lacking fair trial guarantees), the state will be under an obligation to a) enforce these sanctions under its jurisdiction, while b) it will not be exempt from the rule of law obligation to respect the "presumption of innocence" principle. 15 The constituent treaty of an international organization may not contradict jus cogens rules. From this it follows that the organs of the organization may not be empowered to

15 The presumption of innocence is a fundamental right, laid down in the European Convention for the Protection of Human Rights and Fundamental Freedoms (ECHR) and the Charter of Fundamental Rights of the European Union (CFREU). Article 6 of the Treaty on European Union (TEU) provides that the Union shall respect fundamental rights, as guaranteed by the ECHR and as they result from the constitutional traditions common to Member States. The "presumption of innocence" is mentioned in Article 6(2) ECHR (The right to a fair trial): "Everyone charged with a criminal offence shall be presumed innocent until proved guilty according to law" and Article 48 CFREU (Presumption of innocence and right of defense): "I. Everyone who has been charged shall be presumed innocent until proved guilty according to law. 2. Respect of the rights of the defense of anyone who has been charged shall be guaranteed." For more, see, The Presumption of Innocence. Green Paper, Commission of The European Communities. Brussels, 26 April 2006, COM(2006) 174 final. 
violate rules of jus cogens." In the landmark case of T-306/01 and T-315/01, 21 September 2005 - Ahmed Ali Yusuf and Al Barakaat International Foundation ${ }^{16}$ and Yassin Abdullah $\mathrm{Kadi}^{17}$ v. Council of the European Union and Commission of the European Communities', the Court held that the European Community is competent to order the freezing of individuals' funds in connection with the fight against international terrorism. However, insofar as they are required by the Security Council of the United Nations, for the most part, these measures fall outside the scope of judicial review.

The elements of the offence can be proved upon the general rules of Hungarian evidence law. Regarding to subsection 2 paragraph 4 of the Act XIX of 1998 on Penal Procedure, as a main rule, evidence beyond reasonable doubt is needed regardless of the fact whether the crime in question falls within the realm of terrorist offences or not. However, in practice, one can face the fact that in a relatively high number of the cases, criminal responsibility is declared to be proven on solely 'hearsay evidence'. As for organized criminality, subsection 4 of paragraph 77/B. of the HPC institutes the reversal of the onus of proof concerning crimes committed in criminal conspiracy. According to this section, the burden is on the accused to prove the legality of the origin of property gained during the period of taking part in criminal conspiracy. Provided the accused fails to do so, all of his/her property gained in the period in question shall be confiscated upon the presumption of guilt.

Deciding whom to target and how to charge suspects is based predominantly on the information collected by intelligence units and other governmental bodies specialized in terrorism and organized crime. Government Decision No. 2112 of 2004 on the current tasks in the fight against terrorism has set up an Inter-ministerial Anti-terrorist Working Group with the aim of promoting the effective implementation of the relevant international obligations and the policies of European Union. The head of this Group is the Minister of Justice. The body works together with the Counter-terrorism Coordinative Committee set up by Government Decision No. 2239 of 2005. The Committee's main task is to exchange, sum up and analyze the information on suspicious terrorist activities collected by national security authorities in order to prevent the commitment of a potential crime of terrorism. The Committee is operating on the logistical basis of the National Security Office and headed by the deputy director of the Office in question. The Directorate against Organized Criminality also provides its logistical basis available for the Committee.

It must be emphasized that these units do not have independent jurisdictional competence over terrorist finance cases; the jurisdictional authority is left to the ordinary law enforcement authorities operating on the basis of criminal law statutes.

16 Applicants argued that Articles 60 and 301 of EC Directive, on the basis of which that regulation had been adopted authorize the Council solely to take measures against third countries and not, as it did in this case, against nationals of a Member State residing in that Member State. Applicants also denied the allegation that sanctions were imposed on them on account of their association with the regime of the Taliban in Afghanistan. In their view, the sanctions were not imposed on them because they maintained a link with that regime but because of the Security Council's desire to combat international terrorism, regarded as a threat to international peace and security.

17 In support of his/her claims, the applicant has put forward in his application three grounds of annulment alleging breaches of his fundamental rights. The first alleges breach of the right to a fair hearing, the second, breach of the right to respect for property and of the principle of proportionality, and the third, breach of the right to effective judicial review. 
Designation of the accused/suspects appearing on lists related to United Nations Resolutions relative to terrorism (in particular UNSC Resolutions 1267 and 1373) are done on government decrees implementing designation lists of EC regulations and UNSC resolutions. Restrictive measures freezing assets are based on the given government decree.

Having regard that the designation is entirely based on the lists ruled by the EC regulations and UNSC resolutions, therefore the process and the criteria employed in the implementation of the designation are open as much as the legislation of the government is transparent.

Before criminal or other charges, freezing of assets can be taken by government decree. The restrictive measure imposed in the decrees shall be in force until the overruling of the government decree, no limit of time is prescribed in this respect. In the EU and Hungarian law, there are no specific provisions allowing the use of frozen assets for daily and defense expenses. The remedy in case of freezing of assets without any criminal charge shall be directed against the restrictive measure taken in the government decree implementing EC regulation. The process of remedy is ruled in the Government Decree No. 306 of 2004 on the exception process of the financial restrictive measures imposed by the EU. The request for exception shall be submitted to the National Police Headquarters (ORFK) that has to take into account the position of National Security Office and the Ministry of Foreign Affairs, the appeal authority is the Ministry of Internal Affairs. The final decision may be subject to judicial review. The conditions of exception are defined in the EU directives. There is no similar remedy provision for restrictive measures based on the implementation of UNSC resolutions.

As has been highlighted in several international reports, individuals or entities listed under the UNSC sanctions regime are often even unable to appeal their listing, and have no access to any type of independent and impartial review mechanism. While individuals or entities listed under the EU sanctions regimes in theory have access to the courts, many cases demonstrate that the courts' judgments will not always be implemented, creating a dangerous gap between theory and actual practice. It also appears nearly impossible to challenge the legality of the underlying UNSC resolutions and EU decisions - a situation that increases the responsibility on Hungary and other Member States to improve their own proceedings.

Provisions regarding the reparation of innocent suspects whose livelihood and reputation have suffered. Under Hungarian Civil Code, a person whose inherent personal rights have been violated shall have the right to get indemnification for non-pecuniary damages (reputation, pain, distress, suffering, etc..) caused by another person in violation of the law. $\mathrm{S} / \mathrm{he}$ shall be relieved of liability if $\mathrm{s} / \mathrm{he}$ is able to prove that $\mathrm{s} / \mathrm{he}$ has acted in a manner that can generally be expected in the given situation. Whether the government decree imposed the restrictive measure, or the authority in criminal proceedings, it is difficult to argue the legality of the measures, thus damage caused by criminal proceedings and indemnification is unlikely to be subject of judicial procedures. The only possibility to get some compensation or reparation for non-pecuniary damage suffered by innocent suspects is the compensation by law (ex legem). There are no provisions on compensation by law if the restrictive measure were based on a government decree implementing international obligations. Section 580 of HCP allows reparation by law for suspected or charged person in case of acquittance or termination of process. They are entitled to get financial reparation for custody, arrest (detention) on condition that the acquittance or the termination is based on one of the following reasons:

- the subject of charge was not a crime, 
- the subject of charge could not be proven beyond all reasonable doubt,

- the perpetratorship of the charged person could not be proven,

- acquittance on the ground of excuses,

- statutory limitation,

- ne bis in idem.

The acquittance or the termination of process cannot be ground for reparation in any other cases.

\section{FINAL REMARKS}

The problem of terrorism in general, and particularly financing of terrorism also belonged to the core issues of the debate on codifying a new, development-sensitive, comprehensive Criminal Code, which finally resulted in adopting the Act No. C in 2012 entered into force on the 1st of July 2013. The New Criminal Code essentially incorporates the relevant elements of crime of terrorism with the view to make the regulation more transparent. For the sake of this effort, the New Criminal Code splits the content of par 261 of the 1978 Code into three parts, whereby it introduces the crime of 'Terrorism' (Section 314), 'Failing to Report Plans for a Terrorist Act' (Section 317) and 'Financing of Terrorism' (Section 318).

In line with this codification process, significant developments have come to the fore in the field of international judicial cooperation as well. As for Hungarian law, extradition and mutual assistance is possible for the financing of terrorism offence. This possibility is directly based upon Articles 11 and 12 of the International Convention for the Suppression of the Financing of Terrorism, as the Convention has been ratified and implemented into the domestic law so far. Notwithstanding this fact, international judicial cooperation concerning terrorism finance can be based solely on paragraph 6 of the specialized Act No. XXXVIII of 1996 on international judicial cooperation in criminal matters, as Hungary does not make extradition and mutual assistance conditional upon the existence of a treaty between the cooperating parties. (However, the transfer of execution of foreign confiscation orders can be realized only upon specific mutual obligation set forth in an international convention). There is no need for requests or production of prima facie evidence for accepting and acting upon designations by other countries. According to the National Action Plan against Terrorism set by Government Decision No. 2112 of 2004, Hungarian law does not require any formal process through which names of designated individuals or organizations appear on domestic lists, rather Hungary automatically accepts the lists of European Council (EU) and UNSC resolutions. There are two processes where names of individuals or organizations designated by another country or international organization appear on domestic lists published or shared with law enforcement and non-state actors. List of natural or legal persons designated in EC regulation or UNSC resolutions are implemented in a government decree that has to be enforced and respected by each organ and individual, otherwise the crime of violation of international obligation occurs. List of natural or legal persons designated by other countries or international organizations shall be subject of regional or international cooperation in criminal matters ruled by special conventions and domestic rules.

It must be pointed out that, in general, there is no any possibility to speed up international judicial cooperation proceedings on terrorism cases. Expedited response is only possible when the extraditee consents to his/her extradition, as in these cases the simplified extradition proceedings apply (though this is also applicable in other type of 
cases, as the emphasis here lies not on the nature of crime but on the fact of individual consent). The principle of double criminality is applied by the method of the analogous transformation of facts doctrine. Therefore, the Hungarian competent authority has to find a substantially similar offence and it is not necessary to define the offence in the same terms. As far as cooperation with other EU Member States is concerned, it must be emphasized that especially within the frame of European Arrest Warrant scheme-based cooperation, the requirement of double criminality does not apply as a main rule concerning crimes having significant gravity, including financing of terrorism. This rule was first set by subsection 2 paragraph 3 of the Act No. CXXX of 2003 in Hungarian law by implementing the Council Framework Decision on European Arrest Warrant (2002). The rule in question has been further maintained by subsection 2 paragraph 3 of the Act No. CLXXX of 2012 on cooperation with the EU countries in criminal matters replacing the aforementioned Act of 2003. The political offence exception has been abolished within the frame of EU cooperation and within the scope of cooperation with non-EU states it is applicable on the basis of the 'Swiss proportionality theory' embedded in paragraph 5 of Act No. XXXVIII of 1996 on international judicial cooperation in criminal matters. As the International Convention for the Suppression of the Financing of Terrorism has been ratified and implemented into the domestic law so far, directly on the basis of the Convention's provisions, it is now forbidden for the Hungarian authorities to regard crimes of financing terrorism as political offence. Section 28 of Act XXXVIII of 1996 on international judicial cooperation in criminal matters explicitly sets the principle of aut dedere aut judicare for extradition crimes in general. The principle ne bis in idem applies to all extradition crimes on the basis of paragraph 12 of the aforementioned Act, though in a restricted sense. A broader interpretation of the rule, where e.g. decisions of a third state also come into consideration applies only in the realm of cooperation with European Union states upon the Act No. CLXXX of 2012. 